\title{
HCAR3 wt Allele
}

National Cancer Institute

\section{Source}

National Cancer Institute. HCAR3 wt Allele. NCI Thesaurus. Code C51465.

Human HCAR3 wild-type allele is located in the vicinity of $12 \mathrm{q} 24.31$ and is approximately

$2 \mathrm{~kb}$ in length. This allele, which encodes hydroxycarboxylic acid receptor 3 protein, is involved in 3-hydroxyoctanoic acid-dependent G protein-coupled receptor signal transduction 